\title{
The Role of the Limbus in Corneal Allograft Rejection
}

\author{
K. A. WILliAMS AND D. J. COSTER \\ Adelaide, Australia
}

\begin{abstract}
Summary
The state of the recipient peripheral cornea and limbus exerts a strong influence on subsequent corneal graft survival. In particular, graft outcome is influenced by the number of dendritic cells (Langerhans cells) that have infiltrated the graft bed from the limbus. The number of dendritic cells present in the donor button also affects subsequent graft survival.
\end{abstract}

It is a truism that the piece of donor tissue used to replace diseased or damaged recipient cornea during the course of a corneal graft procedure, will be as normal in every way as is possible. Nevertheless, the outcome of corneal transplantation is variable and it is well accepted that recipient factors such as indication for graft, will play a substantial role in determining the eventual post-operative result. ${ }^{1,2} \mathrm{Of}$ all the factors which may influence corneal graft survival, it is our contention that the local environment into which a graft is placed, and in particular the status of what we shall call the graft bed-that is, the residual peripheral cornea, and the limbus of the recipient-is of pre-eminent importance in determining graft outcome.

\section{Vascularisation, graft placement and intraocular pressure}

Corneal vascularisation is an established risk factor for graft failure, irrespective of whether the recipient cornea was vascularised prior to graft, ${ }^{2,3,4}$ or whether vessels have subsequently grown into the cornea and crossed the graft-host junction. Spatial placement of the graft within the recipient graft bed also affects outcome, with eccentrically-placed grafts reportedly being more likely to fail than centrally placed grafts. ${ }^{5,6}$ The effect of graft size upon graft outcome is somewhat controversial. Völker-Dieben and her colleagues have evidence from a series of 1,218 grafts, that larger grafts do less well than do smaller grafts. ${ }^{7}$ In a much smaller series, Tuberville et al. reported no particular correlation between graft size and outcome, ${ }^{8}$ whereas Sanfilippo and his colleagues have actually reported better graft survival with increased graft diameter. ${ }^{9}$ The usual explanation that is advanced for the increased risk of failure observed with vascularised, eccentricallyplaced and (possibly) large grafts, is that proximity to corneal or limbal blood vessels predisposes a graft to immunological rejection, by virtue of concomitant proximity to the host immunocompetent cells to be found within, or close to, those vessels.

Most surgeons will not perform a corneal graft in the face of co-existing raised intraocular pressure, other than in exceptional circumstances, and there is increasing awareness that raised intraocular pressure following corneal transplantation constitutes a threat to the graft as well as to vision. ${ }^{10,11}$ Glaucoma is more likely to occur after corneal transplantation in 
eyes with a past history of raised intraocular pressure; ${ }^{12}$ actuarial survival analysis has shown that graft survival is substantially worse in patients who have had a prior history of raised intraocular pressure, irrespective of whether or not pressure was normal at the time of graft. ${ }^{13}$ This latter point is illustrated in Table I, which shows actuarial corneal graft survival in a cohort of 175 patients treated by a single surgeon (DJC); patients were stratified into two groups according to whether they had had raised intraocular pressure in the past. All patients in each stratum had an intraocular pressure in the normal range, at the time of graft. A difference of over 20 per cent in actuarial graft survival is apparent after 5 years follow-up. The biological basis for this risk factor is not clear; glaucoma is certainly a contributory factor to graft failure in some patients with a history of raised intraocular pressure, but is not the sole reason for failure. Possibly degenerative or mild inflammatory changes in the drainage channels and surrounding limbus may play some as yet undetermined role in graft outcome.

\section{Dendritic cells in cornea and limbus}

Normal human cornea contains infiltrating cells of the dendritic cell lineage; ${ }^{14-23}$ the number of dendritic cells increases with vascularisation, inflammation, disease and graft rejection. ${ }^{22,24}$ Similar findings have been reported in other species. ${ }^{15,16,25-28}$ The possibility that it is actually graft proximity to these infiltrating cells that establishes the risk factor for graft failure in inflamed or vascularised eyes, large or eccentric grafts, or conceivably even eyes with a past history of raised intraocular pressure, will be examined in more detail.

The various end-stage differentiated mem- bers of the dendritic cell family belong to a somewhat ill-defined lineage of bone-marrow derived cells with important antigen-capturing and antigen-presenting cell functions in the normal immune response..$^{29,30}$ Virtually all papers describing corneal dendritic cells have shown that the cells have a characteristic dendritic morphology and carry class II major histocompatibility complex (MHC) antigens. Dendritic cells within the corneal epithelium also carry the CD45 or leucocyte-common antigen, ${ }^{17,22,26}$ are ATP-ase positive, ${ }^{15,23,25-28}$ in man carry the CD1a or T6 antigen ${ }^{21,24,31}$ although there is one report to the contrary, ${ }^{32}$ and possess cytoplasmic Birbeck granules. ${ }^{15}$ They are accordingly referred to as corneal Langerhans cells. Those present in peripheral corneal stroma also appear to carry CD1a ${ }^{21,24}$ but have not been shown to possess Birbeck granules, are variably ATP-ase positive (at least in our hands) and are usually referred to as interstitial dendritic cells.

There are substantial species variations in the number of dendritic cells present in normal cornea, with human and rabbit cornea, for example, containing more epithelial Langerhans cells than either guinea-pig or chicken. ${ }^{15}$ Human and rabbit cornea also contain more stromal interstitial dendritic cells than does rat cornea (Table II). Mouse cornea has been reported to contain virtually no dendritic cells $^{28}$ or relatively few such cells, ${ }^{15,16,25}$ within either central stroma or epithelium.

Within a given species, an additional variation may arise with age. In the mouse, epithelial Langerhans cell numbers have been reported to increase with increasing age to about one year old, and subsequently to decline. ${ }^{25}$ By contrast, however, there is evidence that human infant corneal epithelia

Table I Actuarial corneal graft survival in a cohort of 175 patients, treated by the same surgeon; influence of a past history of raised intraocular pressure on subsequent graft survival

\begin{tabular}{|c|c|c|c|c|c|c|}
\hline \multirow[b]{2}{*}{ History of raised $I O P$} & \multirow[b]{2}{*}{$N^{*}$} & \multicolumn{5}{|c|}{$\begin{array}{c}\text { Actuarial graft survival at given trial time } \\
\text { (years post-graft) }\end{array}$} \\
\hline & & 1 & 2 & 3 & 4 & 5 \\
\hline Never raised & 143 & 88 & 88 & 78 & 72 & 72 \\
\hline Raised in past; not at graft & 32 & 84 & 71 & 60 & 48 & 48 \\
\hline
\end{tabular}

${ }^{*} \mathrm{~N}$ : number initially at risk. 
Table II Passenger cell counts ${ }^{I}$ in central and limbal stroma of normal human, rabbit and rat cornea

\begin{tabular}{|c|c|c|c|c|c|c|}
\hline \multirow[b]{2}{*}{ Species } & \multicolumn{6}{|c|}{$\begin{array}{l}\text { No. positively-stained }{ }^{2} \text { cells } / \mathrm{mm}^{2} \\
\text { mean } \pm S E^{3}\end{array}$} \\
\hline & Number & $\begin{array}{l}\text { Area of } \\
\text { stroma }\end{array}$ & $\begin{array}{l}\text { Negative } \\
\text { control }\end{array}$ & $\begin{array}{l}\text { Leucocyte- } \\
\text { common } \\
\text { antigen }\end{array}$ & $\begin{array}{l}\text { Class I } \\
\mathrm{MHC}\end{array}$ & $\begin{array}{l}\text { Class II } \\
\mathrm{MHC}\end{array}$ \\
\hline \multirow[t]{2}{*}{ Human $^{4}$} & 15 & Central & $0.4 \pm 1$ & $13 \pm 9$ & $20 \pm 25$ & $10 \pm 7$ \\
\hline & & Limbal & $2 \pm 5$ & $51 \pm 30$ & $61 \pm 39$ & $61 \pm 34$ \\
\hline \multirow{2}{*}{ Rabbit } & 10 & Central & $0 \pm 0$ & $2 \pm \quad 2$ & $\mathrm{NT}^{8}$ & $6 \pm 2$ \\
\hline & & Limbal & $0.2 \pm 0.5$ & $170 \pm 101$ & NT & $13 \pm 44$ \\
\hline \multirow[t]{2}{*}{$\mathrm{Rat}^{\mathrm{t}}$} & 20 & Central & $0.2 \pm 1.0$ & $2 \pm 5$ & NT & $4 \pm 3$ \\
\hline & & Limbal & $0.7 \pm 1$ & $19 \pm 12$ & NT & $29 \pm 22$ \\
\hline
\end{tabular}

${ }_{1}$ Calculated as previously described. ${ }^{22}$

${ }^{2}$ Immunoperoxidase staining was carried out as previously described. ${ }^{22.26}$

${ }^{3}$ Standard error of the mean.

${ }^{4}$ Human corneas were eye-bank corneas considered unsuitable for transplantation.

${ }^{5}$ New Zealand white adult females.

${ }^{6}$ Equal numbers of Fisher 344 and DA adult rats.

${ }^{7}$ Monoclonal antibody panels have been previously described for human ${ }^{22}$ and rabbit ${ }^{26}$ corneas; rat corneas were stained with diluent containing 1 per cent $\mathrm{v} / \mathrm{v}$ normal rat serum (negative control); OX-1 (anti-leucocytecommon antigen), OX-6 (anti class II MHC monomorphic determinant), both obtained from Serotec, Oxford, UK.

\& NT: not tested.

(less than 2 years of age) contain significantly more dendritic cells than do older corneas. ${ }^{23}$

It should be noted that even normal cornea may contain small numbers of a variety of other infiltrating leucocytes, including $\mathrm{T}$ cells and macrophages, especially in peripheral cornea and limbus. ${ }^{22,20}$ As more monoclonal antibodies become available, so the phenotypes of cells infiltrating ocular tissues will be more precisely defined. ${ }^{31}$

In summary, the normal cornea of many species contains dendritic cells. Human cornea contains some such cells within the central stroma $^{19,21.22}$ as well as in the central epithelium. In most species studied, the number of cells in normal tissue increases with increasing proximity to the limbus. ${ }^{14,17-20,22,24}$ Cells of the dendritic lineage are often considered to be the so-called 'passenger cells' in transplantable tissues and organs.

\section{Dendritic cells in diseased and damaged corneas}

In 1981, Lang and his colleagues observed that host Langerhans cells moved rapidly into the central cornea of the guinea-pig, following a variety of inflammatory stimuli including penetrating keratoplasty. ${ }^{27}$ More recently,
Pepose et al. have shown substantial numbers of interstitial dendritic cells in the central stroma of rejected human corneal allografts. ${ }^{24}$

Gillette and his colleagues, in an elegant early paper $^{16}$ demonstrated increased numbers of Langerhans cells in the epithelium of excised human corneas, removed at the time of graft from patients with a history of past or present inflammation of the ocular surface, as well as in guinea-pig corneas in which an inflammatory keratitis had been induced by the local injection of endotoxin. We have subsequently confirmed and extended this work, to show that increased numbers of interstitial dendritic cells are also found in the central stroma (as well as the epithelium) of human corneas removed from patients with one or more of the accepted risk factors for subsequent graft failure,$^{22}$ as well as in deliberately vascularised, inflamed rabbit corneas. ${ }^{26}$

Passenger cells counted in vascularised or inflamed human, rabbit and rat corneas are shown in Table III. Clearly, despite individual variations, substantial numbers of cells bearing the leucocyte-common antigen and class II MHC antigens (counted separately on serial sections) are present in the central and limbal 
Table III Passenger cell counts ${ }^{1}$ in vascularised and/or previously inflamed corneal stroma of human, rabbit and rat cornea

\begin{tabular}{|c|c|c|c|c|c|c|c|}
\hline \multirow[b]{2}{*}{ Species } & \multicolumn{7}{|c|}{$\begin{array}{c}\text { No. positively-stained cells } / \mathrm{mm}^{2} \\
\text { mean } \pm S E\end{array}$} \\
\hline & Number & $\begin{array}{l}\text { Area of } \\
\text { stroma }\end{array}$ & $\begin{array}{l}\text { Negative } \\
\text { control }\end{array}$ & $\begin{array}{l}\text { Leucocyte- } \\
\text { common } \\
\text { antigen }\end{array}$ & $\begin{array}{c}\text { Class I } \\
\text { MHC } \\
\text { antigen }\end{array}$ & $\begin{array}{l}\text { Class } \\
\text { II MHC } \\
\text { antigen }\end{array}$ & $\begin{array}{c}\text { Pan } T \\
\text { cell } \\
\text { antigen }\end{array}$ \\
\hline Human $^{2}$ & 47 & Central & $1 \pm 6$ & $101 \pm 154$ & $119 \pm 177$ & $89 \pm 104$ & $12 \pm 22$ \\
\hline \multirow[t]{2}{*}{ Rabbit $^{3}$} & 46 & Central & $1 \pm 3$ & $75 \pm 56$ & NT & $48 \pm 18$ & $38 \pm 19$ \\
\hline & & Limbal & $0 \pm 0$ & $391 \pm 157$ & NT & $237 \pm 52$ & $121 \pm 51$ \\
\hline \multirow[t]{2}{*}{ Rat $^{3}$} & 6 & Central & $0 \pm 0$ & $43 \pm 57$ & NT & $25 \pm 28$ & $15 \pm 22$ \\
\hline & & Limbal & $1 \pm 1$ & $26 \pm 26$ & NT & $29 \pm 19$ & $8 \pm 6$ \\
\hline
\end{tabular}

${ }^{1}$ See legend to Table II.

${ }^{2}$ Corneas removed from patients about to undergo corneal transplantation; all recipients had evidence of corneal vascularisation and/or a history of anterior segment inflammation.

${ }^{3}$ Vascularisation and inflammation induced by prior placement of silk sutures in the cornea.

corneal stroma. Thus, whereas acute inflammatory or infective episodes affecting the cornea usually result in an influx of polymorphonuclear granulocytes, ${ }^{33}$ the late sequelae of inflammation and of vascularisation tend to involve a more heterogeneous infiltrate, in which $\mathrm{T}$ cells can certainly be present. The major component, however, is frequently the dendritic cell.

\section{The relevance of dendritic cells to corneal graft rejection}

Noting that ocular inflammation is often accompanied by an influx of dendritic cells into the cornea, and that the number of dendritic cells can be depleted by treatment with either topical or systemic corticosteroid. Gillette and his colleagues suggested in 1982 that ocular Langerhans cells might play a central role in corneal contact hypersensitivity and graft rejection. ${ }^{16}$ Host-derived dendritic cells certainly appear to be able to move from the limbus into corneal grafts. ${ }^{27.24}$ but their mere presence does not of itself indicate that they play any functional role in graft rejection, and in fact there are strong theoretical reasons (to be discussed below) to suggest that they do not. The potential role of donor-type dendritic cells is more readily apparent.

\section{(a) Removal or inactivation of donor-type} passenger cells

For over ten years, it has been a tenet of transplantation immunology that the major allogeneic stimulus produced by a graft is dependent upon the presence, within that graft, of donor passenger cells, carrying foreign MHC antigens and capable of producing a cytokine, that can interact directly with, and activate, host resting T cells. ${ }^{34}$ This interaction is shown diagrammatically in Fig. 1. A corollary is that removal of such passenger

\section{DIRECT PROCESSING}

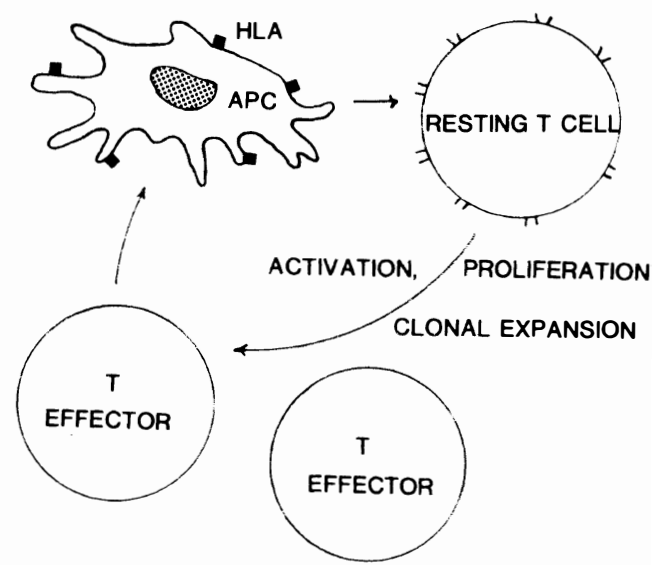

FOREIGN APC CARRIED IN THE GRAFT

CAN STIMULATE HOST T CELLS DIRECTLY

Fig. 1. In direct antigen processing, donor-type antigen-presenting cells (APC) carrying class II MHC antigens (in this case, HLA antigen) present alloantigen directly to host resting $T$ cells. The final outcome in the generation of a population of allospecific effector cells, capable of mediating graft damage. 
cells from a graft, prior to transplantation, should increase the subsequent survival of that graft by reducing the incidence of host sensitisation. ${ }^{35}$ Abundant experimental evidence exists that in some model systems, dendritic cell depletion (or inactivation) by, for example, organ-culture of the graft in an oxygen-rich environment, exposure to ultraviolet radiation or other, similar strategies, will indeed prolong graft survival. ${ }^{35}$ Chandler and his colleagues were the first to extend this approach to the cornea in a series of experiments demonstrating that culture of murine corneas in hyperbaric oxygen, removal of corneal epithelium, ultraviolet irradiation or the soaking of corneas in anti-class II MHC antigen serum plus complement, prior to heterotopic transplantation, reduced the incidence of allograft rejection compared with untreated controls. ${ }^{36,37,38}$ Although an early clinical study suggested that removal of human donor corneal epithelium reduced the incidence of post-operative rejection episodes, ${ }^{39} \mathrm{a}$ later prospective, randomised clinical trial (impeccably analysed) was unable to show any effect on actuarial graft survival. ${ }^{40}$ In view of the evidence that human cornea contains at least some dendritic cells within central stroma, ${ }^{21,22}$ this finding is not surprising. Mouse cornea, as discussed earlier, contains fewer dendritic cells per unit area than does cornea of other species, including man, and the majority of cells present are in the epithelium, a finding which may help to explain the relative ease with which dendritic cell depletion can be achieved in murine models.

Prolonged organ-culture in an oxygen-rich environment is toxic for rabbit corneal endothelium,${ }^{41}$ precluding this approach in a species with a corneal dendritic cell distribution more closely approximating that of man, but ultraviolet radiation of both donor and recipient corneas has been shown to prolong corneal allograft survival in a high-risk rabbit model. ${ }^{42}$ Interestingly, Holland et al. ${ }^{43}$ have demonstrated that long-term corneal organculture under conventional conditions (that is, without either hyperbaric oxygen or an oxygen-rich environment) reduces the number of ATP-ase-positive cells in human and mouse corneas. Völker-Dieben and her colleagues, ${ }^{7}$ in what is probably the first report that dendritic cell depletion may affect clinical corneal graft survival, have subsequently shown a significant improvement in actuarial graft survival in those patients receiving an organ-cultured cornea, compared with those receiving a moist-pot or McCarey-Kaufman medium stored cornea.

\section{(b) The effects of increased numbers of} donor dendritic cells on graft survival

Further evidence for the importance of donorderived dendritic cells in the immune response to a corneal graft, comes from studies in which the number of donor dendritic cells has been deliberately and artificially augmented in the cornea, prior to transplantation. Such corneas, transplanted to heterotopic sites in the mouse ${ }^{28}$ or to orthotopic sites in the rabbit ${ }^{26}$ or the rat, ${ }^{44}$ are more immunogenic than are normal corneas. Dendritic cells of donor origin have been shown to be necessary for the generation of delayed-type hypersensitivity (but not cytotoxic $\mathrm{T}$ cell) responses to corneal alloantigen, in both mouse and rat. ${ }^{45,44}$

\section{(c) Indirect processing: are recipient dendritic cells important in $\mathrm{MHC}$-restricted responses to alloantigen?}

In recent work from our own laboratory, we have found that, in a cohort of 70 patients with evidence of corneal neovascularisation and/or a history of anterior segment inflammation or other risk factor for graft failure, the number of leucocyte-common antigen-positive cells in the recipient bed at the time of transplantation is associated with eventual outcome. ${ }^{46}$ Thus, actuarial corneal graft survival in those patients with fewer than 50 cells $/ \mathrm{mm}^{2}$ of central corneal stroma was 73 per cent at three years, compared with 41 per cent in those patients with counts in excess of 50 cells $/ \mathrm{mm}^{2}$. In addition we have shown that dendritic cells isolated by enzymatic disaggregation from vascularised rat corneas can present an artificial antigen to purified syngeneic $T$ cells, that is, corneal dendritic cells have antigen-presenting cell capabilities. ${ }^{42}$ Interestingly, Williamson and co-workers have recently reported that the presence of substantial numbers of murine Langerhans cells in the central epithelium of murine corneas, can 
impair the usual suppression of the immune response that is observed when tumour cells (bearing incompatible minor transplantation antigens) are engrafted into the anterior chamber. ${ }^{47}$ None of these experiments have demonstrated, however, that recipient corneal dendritic cells are capable of presenting incompatible major histocompatibility antigens to host $\mathrm{T}$ cells.

Indirect processing of foreign alloantigen by recipient accessory cells is widely believed either not to occur at all, or to be irrelevant to graft destruction because of the MHCrestricted nature of the response. The recent description of the structure of a crystalline human MHC class I antigen, with a deep groove identified as the binding site for processed foreign antigens, has reinforced current theories on the role of MHC antigens in antigen-processing and subsequent $\mathrm{T}$ cell recognition. ${ }^{48}$ Because the $\mathrm{T}$ cell receptor normally recognises foreign antigen fragments in association with self MHC antigens and the resulting $\mathrm{T}$ cell clone is MHCrestricted, indirect processing of foreign MHC antigen shed from a graft might conceivably result in sensitisation ( $\mathrm{T}$ cell recognition of self MHC plus foreign MHC antigen),

INDIRECT PROCESSING

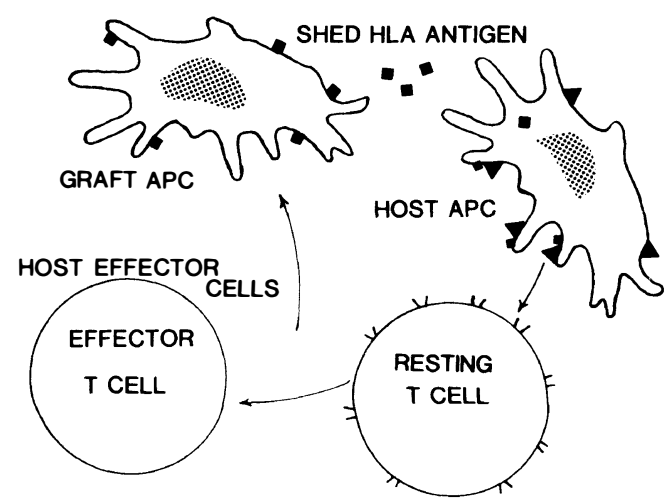

HOST APC PROCESS GRAFT ANTIGENS

Fig. 2. In indirect processing, foreign $M H C$ antigen (in the case, HLA antigen shed from a passenger cell in the graft) is picked up by a host-type antigen-presenting cell and presented in the context of self $M H C$ antigen to a syngeneic (host-type) antigen-reactive $T$ cell. The resulting self-MHC-restricted effector cells may be capable of mediating graft damage in situations of partial MHC identity between host and donor. but graft damage would not occur where host and donor were totally MHC incompatible. Under circumstances of total or partial MHC compatibility, however, indirect processing of minor transplantation antigens (or the incompatible major alloantigens) could possibly lead to efferent-arm damage to the graft. ${ }^{49,50}$ This is shown diagrammatically in Fig. 2.

In vitro studies have shown that murine recipient-type accessory cells are capable of acquiring, processing and presenting shed class I MHC antigens to self-class II MHC antigen-restricted $\mathrm{T}$ helper cells. ${ }^{51}$ The cardinal work of Lechler and Batchelor, ${ }^{52}$ demonstrating primarily the importance of direct interactions between donor-strain dendritic cells and host alloreactive $\mathrm{T}$ cells in in vivo responses to rat renal grafts, also suggested a lesser role for indirect processing of alloantigen. In a quite different murine cell transfer system, Sherwood and her colleagues also found evidence for alloantigen presentation by host accessory cells in vivo. ${ }^{53} \mathrm{We}$ and others have proposed that a similar mechanism may operate in the immune response to a partiallymatched corneal graft. ${ }^{42.45}$

There is ample evidence from a large number of studies ${ }^{19,20,17,18,21,22}$ that class I MHC antigens are expressed on normal corneal epithelium, and some evidence that expression increases from central to peripheral cornea. ${ }^{19}$ Although most studies have reported that class I antigens are absent from adult corneal endothelium, ${ }^{20,17,18,21,22}$ there are notable exceptions, ${ }^{19,54}$ and there is agreement that class I antigens can be found on endothelia removed from donors younger than about 2 years. ${ }^{19,20}$ Whereas class II antigens are absent from healthy epithelium, keratocytes and endothelium, there is clear evidence that expression can be induced, at least on endothelial cells, under the influence of regulatory cytokines $^{55.56}$ and on endothelial, stromal and basal epithelial cells in rejected corneal grafts. ${ }^{24}$ Upregulation of the expression of class I and II antigens had previously been shown to occur in other tissues during rejection,,$^{57,58,59}$ and class I antigens at least can be upregulated by surgery alone. ${ }^{59}$ It would thus appear that the requisite sets of target antigens for an MHC-restricted efferent re 
sponse, may well be present on corneal graft tissue.

In summary, the possibility that indirect antigen processing can occur in the cornea, and may affect the outcome of corneal transplantation, cannot easily be dismissed.

\section{Conclusions and Implications}

The limbus may be considered as a conduit through which vessels, immunocompetent cells and their products enter the cornea. Normal cornea contains cells with the morphology and phenotype of immunological accessory cells in epithelium and (in man) in stroma; the number of these cells increases substantially towards the peripheral cornea and limbus. Many inflammatory processes involving the cornea or anterior segment appear to result eventually in an influx of leucocytes from the limbus into the cornea; the infiltrates are heterogeneous but frequently contain a preponderance of dendritic cells, which may persist for considerable times following the resolution of the original inflammatory episode. Leucocytic infiltration follows both non-specific inflammation and immunologically specific responses such as graft rejection.

The number of infiltrating cells in the recipient bed of a corneal graft, correlates well with eventual outcome, as does the number of such cells carried within the donor tissue. The question arises as to whether these cells play a direct role in graft rejection, or whether they are markers for some unidentified immunological process. Dendritic cells carried as passenger cells within a corneal graft almost certainly interact directly with host alloantigen-specific $\mathrm{T}$ cells, initiating sensitisation and subsequent effector-phase damage. There is evidence both that increasing the number of donor passenger cells in the donor button increases the likelihood of sensitisation and subsequent rejection, and that decreasing their numbers reduces the likelihood of sensitisation. From a theoretical viewpoint, it might be expected that larger corneal grafts, carrying more MHC antigen, more passenger cells and being in closer apposition to immunocompetent cells in the limbus, would show poorer survival than smaller grafts.
The precise role of dendritic cells and other immunocompetent cells of recipient origin in the bed of a corneal graft is less well substantiated, but such cells may be involved in indirect antigen processing in situations where donor and recipient are partially matched for class II MHC antigens. It follows that matching for HLA class II antigens may not necessarily improve corneal graft survival in all cases, and in fact the clinical evidence on this point is controversial. ${ }^{7,60}$ It also follows that manipulations designed to remove all passenger cells from a donor button, prior to corneal transplantation, may materially improve graft survival, but may not be successful in every case.

The authors thank Susan Rosewarne for preparing the manuscript.

\section{References}

${ }^{1}$ Coster DJ: Factors affecting the outcome of corneal transplantation. Ann Roy Coll Surg Engl 1981, 63: $91-7$.

2 Völker-Dieben HJM: The effect of immunological and non-immunological factors on corneal graft survival. Dordrecht. Dr. W Junk Publishers, i 984: 1-174.

3 Batchelor JR, Casey TA, Werb A, Gibbs DC, Prasad SS, Lloyd DF, James A: HLA matching and corneal grafting. Lancet 1976, i: 551-4.

${ }^{4}$ Khodadoust AA: The allograft rejection: the leading cause of late failure of clinical corneal grafts. In: Porter R, Knight J eds. Corneal graft failure. Ciba Foundation Symposium 15 (new series). Amsterdam. Elsevier Excerpta Medica NorthHolland 1973: 151-167.

: Khodadoust AA and Silverstein AM: Studies on the nature of the privilege enjoyed by corneal allografts. Invest Ophthalmol 1.972, 11: 137-48.

${ }^{6}$ Wessels IF and Dahan E: Eccentric corneal grafts. Am J Ophthalmol 1986, 101: 113-4.

- Völker-Dieben HJ, D’Amaro J. Kok-van Alphen CC: Hierarchy of prognostic factors for corneal allograft survival. Aust NZ J Ophthalmol 1987. 15: $11-18$.

8 Tuberville AW, Foster CS, Wood TO: The effect of donor cornea epithelium removal on the incidence of allograft rejection reactions. Ophthalmol 1983, 90: 1351-6.

${ }^{9}$ Sanfilippo F, MacQueen JM, Vaughn WK, Foulks GN: Reduced graft rejection with good HLA-A and $\mathrm{B}$ matching in high-risk corneal transplantation. New Engl J Med 1986, 315: 29-35.

${ }^{10}$ Thoft RA, Gordon JM, Dohlman CH: Glaucoma following keratoplasty. Trans Am Acad Ophthalmol Otolaryng 1977, 78: 352-64.

$"$ Foulks GN: Glaucoma associated with penetrating keratoplasty. Ophthalmol 1987, 94: 871-4.

12 Goldberg DB, Schanzlin DJ, Brown SI: Incidence of 
increased intraocular pressure after keratoplasty. Am J Ophthalmol 1981, 92: 373-7.

${ }^{13}$ Williams KA, Sawyer MA, White MA, Mahmood MI, Coster DJ (on behalf of all contributors): Report from the Australian corneal graft registry. Transplant Proc (in press).

${ }^{14}$ Klareskog L, Forsum U, Tjernlund UM, Rask L, Peterson PA: Expression of Ia antigen-like molecules on cells in the corneal epithelium. Invest Ophthalmol Vis Sci 1979, 18: 310-13.

${ }^{15}$ Rodrigues MM, Rowden G, Hackett J, Bakos I: Langerhans cells in the normal conjunctiva and peripheral cornea of selected species. Invest Ophthalmol Vis Sci 1981, 21: 759-65.

${ }_{16}$ Gillette TE, Chandler JW, Greiner JV: Langerhans cells of the ocular surface. Ophthalmol 1982, 89: 700-10.

${ }^{17}$ Mayer DJ, Daar AS, Casey TA, Fabre JW: Localization of HLA-A,B,C and HLA-DR antigens in the human cornea; practical significance for grafting technique and HLA typing. Transplant Proc 1983, 15: 126-9.

${ }^{18}$ Fujikawa LS, Colvin RB, Bhan AK, Fuller TC, Foster CS: Expression of HLA-A/B/C and -DR locus antigens on epithelial, stromal and endothelial cells of the human cornea. Cornea 1982, 1: 213-22.

19 Treseler PA, Foulks GN, Sanfilippo F: The expression of HLA antigens by cells in the human cornea. Am J Ophthalmol 1984, 98: 763-72.

${ }^{20}$ Whitsett CF and Stulting RD: The distribution of HLA antigens on human corneal tissue. Invest Ophthalmol Vis Sci 1984, 25: 519-24.

${ }^{21}$ Vantrappen L, Geboes K, Missotten L, Maudgal PC, Desmet V: Lymphocytes and Langerhans cells in the normal human cornea. Invest Ophthalmol Vis Sci 1985, 26: 220-5.

22 Williams KA, Ash JK, Coster DJ: Histocompatibility antigen and passenger cell content of normal and diseased human cornea. Transplantation 1985, 39: 265-9.

${ }^{23}$ Chandler JW, Cummings M, Gillette TE: Presence of Langerhans cells in the central corneas of normal human infants. Invest Ophthalmol Vis Sci 1985, 26: 113-16.

${ }^{24}$ Pepose JS, Gardner KM, Nestor MS, Foos RY, Pettit TH: Detection of HLA class I and II antigens in rejected human allografts. Ophthalmol 1985, 92: 1480-4.

${ }^{25}$ Hazlett LD, Grevengood C, Berk RS: Change with age in limbal conjunctival epithelial Langerhans cells. Curr Eye Res 1981, 1: 161-7.

${ }^{26}$ Williams KA, Mann TS, Lewis M, Coster DJ: The role of resident accessory cells in corneal allograft rejection in the rabbit. Transplantation 1986, 42: 667-71.

${ }^{27}$ Lang RM, Friedlaender MH, Schoenrock BJ: A new morphologic manifestation of Langerhans cells in guinea pig corneal transplants. Curr Eye Res 1981, 1: 161-7.

${ }^{28}$ Rubsamen PE, McCulley J, Bergstresser PR, Streilein JW: On the Ia immunogenicity of mouse corneal allografts infiltrated with Langerhans cells. Invest Ophthalmol Vis Sci 1984, 125: 51318.

${ }^{29}$ Steinman RM and Witmer MD: Lymphoid dendritic cells are potent stimulators of the primary mixed leukocyte reaction in mice. Proc Natl Acad Sci USA 1978, 75: 5132-6.

${ }^{30}$ Steinman RM and Nussenzweig MC: Dendritic cells: features and functions. Immunol Rev 1980, 53: $127-47$.

${ }^{31}$ Sacks E, Rutgers J, Jakobiec FA, Bonetti F, Knowles DM: A comparison of conjunctival and nonocular dendritic cells utilizing new monoclonal antibodies. Ophthalmol 1986, 8: 1089-484.

32 Seto SK, Gillette TE, Chandler JW: HLA-DR+/ T6 $^{-}$. Langerhans cells of the human cornea. Invest Ophthalmol Vis Sci 1987, 28: 1719-22.

${ }^{33}$ Badenoch PR, Finlay-Jones JJ, Coster DJ: Enzymatic disaggregation of the infected rat cornea. Invest Ophthalmol Vis Sci 1983, 24: 253-7.

${ }^{34}$ Lafferty KJ, Andrus L, Prowse SJ: Role of lymphokine and antigen in the control of specific $\mathrm{T}$ cell responses. Immunol Rev 1980, 51: 279-314.

${ }^{35}$ Lafferty KJ: Immunogenicity of foreign tissues. Transplantation 1980, 29: 179-82.

${ }^{36}$ Chandler JW, Ray-Keil L, Gillette TE: Experimental corneal allograft rejection: description of murine model and a new hypothesis of immunogenesis. Curr Eye Res 1982/3, 2: 387-97.

${ }^{37}$ Ray-Keil L and Chandler JW: Rejection of murine heterotopic corneal transplants. Transplantation 1985, 39: 473-7.

${ }^{38}$ Ray-Keil L and Chandler JW: Reduction in the incidence of rejection of heterotopic murine corneal transplants by pretreatment with ultraviolet radiation. Transplantation 1986, 42: 403-6.

${ }^{39}$ Tuberville AW, Foster CS, Wood TO: The effect of donor cornea epithelium removal on the incidence of allograft rejection reactions. Ophthalmology 1983, 90: 1351-6.

${ }^{40}$ Stulting RD, Waring GO, Bridges WZ, Cavanagh HD: Effect of donor epithelium on corneal transplant survival. Ophthalmology 1988, 95: 803-12.

${ }^{41}$ Williams KA and Coster DJ: Donor and recipient therapeutic manipulations to prevent corneal allograft rejection. In Cavanagh $\mathrm{HD}$, ed. The Cornea-Transactions of the World Congress on the Cornea III, New York: Raven Press 1988 (in press).

42 Williams KA, Ash JK, Mann TS, Noonan FP, Coster DJ: Cells infiltrating inflamed and vascularized corneas. Transplant Proc 1987, 19: 2889-91.

${ }^{43}$ Holland EJ, De Ruyter DN, Doughman DJ: Langerhans cells in organ-cultured corneas. Arch Ophthalmol 1987, 105: 542-5.

${ }^{44}$ Callanan D, Peeler J, Niederkorn JY: Characteristics of rejection of orthotopic corneal allografts in the rat. Transplantation 1988, 45: 437-43.

${ }^{45}$ Peeler JS and Niederkorn JY: Antigen presentation by Langerhans cells in vivo: donor-derived $\mathrm{Ia}^{+}$ Langerhans cells are required for induction of delayed-type hypersensitivity, but not for 
cytotoxic T lymphocyte reponses to alloantigens. J Immunol 1986, 136: 4362-71.

46 Williams KA, White MA, Ash JK, Coster DJ: Leucocytes in the graft bed are associated with corneal graft failure: analysis by immunohistology and actuarial graft survival. Ophthalmology (in press).

${ }^{47}$ Williamson JSP, DiMarco S, Streilein JW: Immunobiology of Langerhans cells on the ocular surface. 1. Langerhans cells within the central cornea interfere with induction of anterior chamber associated immune deviation. Invest Ophthalmol Vis Sci 1987, 28: 1527-32.

${ }^{48}$ Bjorkman PJ, Saper MA, Samraoui B, Bennett WS, Strominger JL, Wiley DC: The foreign antigen binding site and $T$ cell recognition regions of class I histocompatibility antigens. Nature 1987, 329: 512-81.

${ }^{49}$ Loveland B and Simpson E: The non-MHC transplantation antigens: neither weak nor minor. Immunology Today 1987, 7: 223-9.

${ }^{50}$ Silvers WK, Kimura H, Desquenne-Clark L, Miyamoto M: Some new perspectives on transplantation immunity and tolerance. Immunology Today 1987, 8: 117-22.

${ }^{51}$ Golding $\mathrm{H}$ and Singer A: Role of accessory cell processing and presentation of shed $\mathrm{H}-2$ alloantigens in allospecific cytotoxic $\mathrm{T}$ lymphocyte responses. J Immunol 1984, 133: 597-605.

52 Lechler RI and Batchelor JR: Restoration of immunogenicity to passenger cell-depleted kidney allografts by the addition of donor strain dendritic cells. J Exp Med 1982, 155: 31-41.

${ }^{53}$ Sherwood RA, Brent L, Rayfield LS: Presentation of alloantigens by host cells. Eur J Immunol 1986, 16: $569-74$.

${ }^{54}$ Treseler PA and Sanfilippo F: The expression of major histocompatibility complex and leukocyte antigens by cells in the rat cornea. Transplantation 1986, 42: 248-52.

55 Young E, Stark WJ, Prendergast RA: Immunology of corneal allograft rejection: HLA-DR antigens on human corneal cells. Invest Ophthalmol Vis Sci 1985, 26: 571-4.

56 Donnelly JJ, Rockey JH, Prendergast RA: Induction of class II (Ia) alloantigen expression on corneal endothelium in vivo and in vitro. Invest Ophthalmol Vis Sci 1985, 26: 575-80.

${ }^{57}$ Dallman MJ and Mason DW: Induction of Ia antigens on murine epidermal cells during the rejection of skin allografts. Transplantation 1983, 36: 222-34.

${ }^{58}$ Hall BM, Bishop GA, Duggin GG, Horvath JS, Philips J, Tiller DJ: Increased expression of HLA-DR antigens on renal tubular cells in renal transplants: relevance to the rejection response. Lancet 1984, ii: 247-51.

${ }^{59}$ Milton AD and Fabre JW: Massive induction of donor-type class I and class II major histocompatibility complex antigens in rejecting cardiac allografts in the rat. $J$ Exp Med 1985, 161: 98-112.

${ }^{60}$ Boisjoly HM, Roy R, Dubé I, Laughrea PA, Michaud R, Douville P, Hébert J: HLA-A,B and DR matching in corneal transplantation. Ophthalmol 1986, 93: 1290-7. 